\title{
Market-driven global directives and social responsibility in higher education
}

\begin{abstract}
Authors:
Prof Frederick J Veldman ${ }^{1,2}$

Affiliation:

${ }^{1}$ Sefako Makgatho Health Sciences University,

South Africa

${ }^{2}$ Doctoral candidate, International Centre for Higher Education Management, University of Bath, United Kingdom
\end{abstract}

\section{Correspondence to:}

Prof Frederick J Veldman,

School of Health Care

Sciences,

Sefako Makgatho Health

Sciences University,

Medunsa,

Molotlegi Street,

Ga-Rankuwa Zone 1,

Ga-Rankuwa, 0208

Pretoria North,

South Africa

Tel:

+27 794744163

\section{E-mail:}

frederick.veldman@smu. ac.za

DOI:

10.15249/12-1-168

\section{Keywords:}

globalisation; higher education; social justice; universities; public good

\section{Abstract}

Liberation from human suffering is an honourable achievement, but without release from the constraints of impoverishment, sovereignty is partial. The South African Constitution envisions such a socially just environment based on democracy, equity and respect. Local public Higher Education Institutions (HEIs) therefore have a social contract to align themselves with these principles. This is a daunting responsibility, especially in a time when these institutions have become subjected to the demands of a globalised market-driven mentality that requires of them to function in a financially competitive style, often at the expense of their social responsibility.

\section{Introduction}

Globalisation is defined as a process that develops a wider and deeper global interconnectedness (Held et al., 2000:15) and is often referred to as the process of "McDonaldization" (Porter \& Vidovich, 2000:451). Within a post-modern globalised environment, and in the time of knowledge as a commodity, Higher Education Institutions (HEls) become re-defined: as Heidegger has warned us, they become a currency to be used as part of the reservoir in the game of national monetary warfare (Peters \& Humes, 2003:439). Howard-Hassmann (2005) insists that capitalism and social justice are mutually inclusive, whereas capitalism is also a superior "political system to grow civil rights". In such an ideal setting, globalisation eventually leads to the strengthening of cosmopolitan attitudes by weakening the relevance of ethnicity, geographical location, or nationalism as sources of identification. Simultaneously, it increases the interconnectedness of people worldwide and broadens the group boundaries within which individuals perceive 
they belong (Buchan et al., 2009:4138). Yet, some intellectuals also reason that globalisation prompts reactionary movements that reinforce conservative distinctions among people. Large-scale cooperation then focuses on favouring one's own ethnic, racial, or language group. In this article, the author provides a valuable map of contemporary HEls within the context of globalisation. He gives a summary of the concept of social justice and challenges the widely accepted notion that globalisation and social justice are mutually inclusive.

\section{Globalisation defined}

To operationalise and defend the reconciliation among numerous factors of globalisation, Jones (1998:145) has distinguished between various contexts within which activities take place: economic globalisation, political globalisation and cultural globalisation. Despite identification of different forms of globalisation, it is the economic principles that have dominated the policy agenda of Western nation-states as they attempt to position themselves favourably in competitive global markets (Porter \& Vidovich, 2000:453). There is no doubt, however, that even within the economic context, in all the strategies for national development in the twenty-first century, HEls also play a key role. Many analysts have argued that the implications of globalisation for HEls are substantial (Porter \& Vidovich, 2000:453). With growing interdependence and convergence, HEls, as an industry, respond and are affected in many different dynamic ways (Van der Wende, 2007:274). The higher education market is globally very well established, even though not all universities consider themselves to be international per se. Most HEls, however, have recognised the requirement to market themselves in a highly competitive [economic] climate (Hemsley-Brown \& Oplatka, 2006:316).

The strategies used to align HEls with the needs of a contemporary globalised environment are widespread. These strategies, however, all have one single common goal in mind, which is to strengthen institutional capacity to compete, on a local, regional and international level, for talented students, well-educated staff, research funding, etc. It has become ever clearer that HEls cannot be understood without recognising that their policies and practices are significantly influenced by an integrated international market. Unfortunately, it is also true that this market is submissive to severe fluctuation and that HEls are also affected by it - that reforms and instability in one country significantly affect others, that immigration and population flows from one nation or area to another significantly impact on what is officially counted as knowledge, what counts as responsive and effective education, what defines relevant teaching, etc. (Burbules \& Torres, 2000:18). All these social and ideological dynamics and many more now fundamentally define what education does, how it is controlled, and who benefits from it, globally (Apple, 2011:223). Globalisation, therefore, is not controlled by individual HEls or governments. Eventually, all HEls are submissive to the same demands of globalisation - partly as objects, or even victims of these processes, but mostly as subjects, or key role-players (Scott, 1998:122). The activities of HEls as a commodity have internationally become very well recognised; even though some universities do not consider themselves to be global per se. 
The way the world is structured at this very moment, however, has made it impossible for HEls to isolate themselves (Marginson \& Van der Wende, 2007:5) and it has become evident that institutions cannot be managed without giving recognition to the fact that most of their activities are significantly affected by an increasingly integrated global market. In general, cultural, economic and political models are blended. To fit in with this model, HEls in a global context need to locate themselves by asking whether their function is that of an extended social contract, economic contract, or both. In terms of the policy goals of efficiency, effectiveness, responsiveness and competition embodied in many institutional reform programmes, national authorities prefer to transform their public HEls from national organisations with multiple social roles into global players mainly operating on the basis of economic considerations (Maassen \& Cloete, 2006:9). The coordinating powers of HEls thus found themselves in a highly challenging environment. In an attempt to dissolve the tension, the Organisation for Economic Cooperation and Development OECD (2006:276), on the future of HEls, took two central variables, that is, the extent of globalisation (global-local) and the amount of influence of (state) government (administration-market), as two main dimensions with which they created different scenarios that provide a breakdown into cause and effect, as it relates to globalisation.

\subsection{Open networking}

This is driven by the 'harmonisation' of educational systems and relies heavily on the expansion of agreements such as the Bologna process to have a real-time impact. Those who follow this process, rely on the fact that it will lead to an increased trust in the system and recognition by others as a basis for global 'quality control' (i.e. prior learning). Yet, this requires further internationalisation of institutions through formal collaboration, especially by the facilitation of 'open source' learning, distance learning, and sharing of data and knowledge resources. The main obstacle in this process is the fact that there exists a strong hierarchy among HEls and that 'shared information' is not always relevant to the disadvantaged institutions and the communities they serve.

\subsection{New public responsibility}

This is driven primarily by budget pressures (i.e. corruption, disinvestment, aging society, etc.) and has resulted in stronger public accountability systems. The collective impact of these factors is significant. The scenario relies heavily on increased autonomy, accountability, deregulation of registration fees, etc.

\subsection{Higher Education Inc.}

This scenario relies mainly on 'trade liberalisation' of HEls or on bilateral free-trade agreements. This scenario is exclusively market-driven and competitive. HEls compete globally and there exists aggressive competition for excellent staff and academically strong learners. Many international HEls open satellite campuses abroad and offer 
academic programmes. As private HEls, some charge exorbitant tuition fees. Entering foreign space often leads to disconnected teaching and research that, at times, can be irrelevant to the actual needs of local communities. International rankings significantly strengthen the competitive potential of an institution, as it is the reputation of an institution that draws students and staff.

\subsection{Serving local communities}

This is driven by a movement that does not support internationalisation, and has a strong adverse reaction to globalisation. A fear of losing cultural identity, problems with immigration, regional and international political tensions, and outsourcing seem to be central to this scenario. HEls respond to these threats, however, by investing in research areas such as the launch of more military research, with a shift of attention to local imperatives, sometimes at the cost of the human and social sciences. It seems that local communities benefit little from this scenario.

Each of these scenarios highlight the sensitivity of HEls to the environment in which they function, and aligned with that, how the role of public and private enterprise may have lasting consequences for how we manage institutions. In addition, institutional profile, potential and location further impact the challenges and opportunities that exist. HEls in low-income countries often struggle to compete (Pettinger, 2007) locally, but especially with international institutions. Universities in low-income settings, in general, compete at much higher costs, when compared to advanced universities in the West, which benefit from years of experience and economies of scale (Pettinger, 2007).

One of the key issues is that there exists real tension around the teaching-research nexus in HEls (Van der Wende, 2007:68). Intellectual property is a commodity of significant value and can be used to strengthen institutional capacity to compete. In accordance with the heightened expectations for funding agencies to pay staff salaries, 'soft-money' job descriptions are primarily linked to research activities and decreasingly based on teaching. This system, from a monetary point of view, seems highly attractive. The downside is that the nature of research becomes driven primarily by the priorities of industry, which is where the financial support comes from. Hemsley-Brown and Oplatka (2006:325), in their systematic review, concluded that research agendas of HEls appear to be more on par with the features and processes of industrial/commercial/business services marketing, instead of particular features and processes of HEls and services.

Focus on the research function of universities highlights the reality of institutional diversity. Yet, the more notable specialisation and focus on research and related greater institutional diversity have extensive negative effects on the internationalisation agenda. By favouring the international agenda that exists within the heterogeneous field of HEls' research reputation, international rankings exercise some 'hegemonic' influence over competing field dialectics (Enders, 2014:155), providing new tools for constructing credibility and measuring status. The issue is that the system is effective in creating a sub-field of 'world-class universities', which contribute to the establishment of belonging 
and distinction and set out rules and criteria for those who are or want to be part of the 'club'. An important consideration, therefore, is whether research directives in the context of globalisation should be defined within a local context, or rather by this subgroup of elitist institutions. This could, essentially, direct institutional research towards local 'community-specific' needs, or alternatively, 'international challenges'. Current ranking-driven competition for institutional reputation exceeds the need of institutions to become competitive in terms of local societal needs (Van der Wende, 2008:277).

The "reputation race" leads to additional cost explosions (Van Vught, 2006). Institutions respond in diverse ways to the increased financial demands, such as attracting more international students (Haigh, 2008:427), or alternatively, by increasing local student enrolment (massification). Already in 2012, there were nearly 900000 students in South Africa's public universities, including full-time, part-time and distance students. This represents a nearly $82 \%$ increase in student numbers since the advent of democracy, when there were 495000 students (MacGregor, 2012). The National Development Plan (NDP) requires that by 2030, South African universities will enrol 1.6 million students. However, 'massification' of HEls in Western nations has been accompanied by a decline in government support for local learners (Bok, 2003:6), and a consequent tendency to lean towards privatisation of HEls. Massification therefore defeats its intended purpose. The South African funding model is based on a five-year student enrolment plan. HEls have limited flexibility in terms of increasing student enrolment beyond this plan. South African universities therefore have the following limited options in building their international reputation:

1. Improved/increased research productivity: The South African per capita research output units have shown a 79\% increase between 2005 and 2014. This reflects an average annual growth of $7.9 \%$. It must also be recognised that not all local HEls are research intensive and hence the growth for the sector seems to be slow, but when comparing institutional data there are huge differences in performance among institutions (DHET, 2016:30). Several criticisms have been raised regarding the potential negative impact of research output audits on research quality. One of the major concerns is the encouragement of researchers to publish as many papers as possible (salami slicing) and to preferentially choose to publish in those journals that have the least rigorous review process (Woodiwiss, 2012:423). Other major strategies aimed at improving research productivity include the appointment of international staff in highly specialised positions strategic to the research agenda of an institution. However, hiring staff with good 'international' credentials is an expensive exercise, and often happens at the cost of the demise of local academics. Yet, if HEls build research strength through the weakening of other local institutions, it does not seem to benefit national capacity (Van der Wende, 2007:279). The outcome of this phenomenon requires further investigation.

2. Attracting the most talented students, sometimes at the expense of students who come from poor, disadvantaged, rural communities: Students who attended primary and secondary schools that historically served black students typically perform 
poorly at university: Grade 12 pass rates for black students are often half of those of white students (Govender, 2013). Only 28\% of students in the National Student Financial Aid Scheme of South Africa (NSFAS), which provides funding mainly to disadvantaged students, make it to graduation (Govender, 2013).

Too simplistic or one-sided competitive models enhance vertical differentiation by building strength in certain institutions or areas by weakening others, and may in fact result in less diversity (Van der Wende, 2007:282). In effect, the outcome of this process will depend on whether institutional strategies for international positioning and profiling largely depend on competition or cooperation. Market-driven systems promote competitive behaviour. There is a concern that local competition will prove too intense though, especially for small disadvantaged institutions.

\section{Globalisation and the South African Council for Higher Education}

In South Africa, the principles of globalisation have been driven by the imperatives of contributing towards building a democratic nation and responding effectively to the challenges of the global era (Country Paper: South Africa. Department of Education, 2000:24). The post-apartheid transformation in South Africa and the imperatives of the global environment called for a radical redefining of the foundation of education - what it means to learn, teach and what is meant by knowledge (Country Paper: South Africa. Department of Education, 2000:27).

In the apartheid era, there was a complete denial of social and political factors that might impact on universities, even in a country that appeared to be on the brink of a revolution. Institutional practices that prescribed that entry to a university should be based purely on academic criteria and should be free from social categories such as race, class or gender functioned to exclude moral and political pressures to address the issue of discrimination (Naidoo, 2004:252). Currently, global contexts must be considered after HEls in low-income countries have begun to integrate into the international community to meet with its demands and comply with international practice. This movement in the university environment, in addition to the fact that most South African HEls remained with management systems inherited from the apartheid regime, required institutional renewal. Local HEls:

1. adopted international university management models of recognised 'elite' institutions; and/or

2. chased after global partnerships and collaborations.

In an environment with new management models, international collaborations and partnerships with industry, local HEls expected of academic staff to generate thirdstream income. In "SOUTH AFRICA: Third stream income a new priority", MacGregor (2008) states that under growing pressure from the South African Department of Higher Education to limit increasing registration fees, HEls were desperate to attract additional 
income by running their institutions as businesses. Institutions were forced to identify external sources of income, or save money (HESA, 2008:15). Institutions explored different ways of generating third-stream income, but, in general, progress was limited by overall poor collaboration between HEls and private industry; South Africa's restricted industrybusiness base; limited tax benefits for industry or the private individual; poor alumni and weak structures for generating external funding; a limited culture of donating; poor research capacity of some institutions; low socio-demographic positioning; and financially weak positions of certain HEls (MacGregor, 2008).

Consequently, local academic staff had to redefine themselves as research-led teachers and suddenly the expectation was there of academic staff to develop Business Plans for Research Units, identify 'niche' profit-generating opportunities, etc. Unfortunately, the competitive greed of universities, 'research income'-desperate academic staff, a neoliberal open market (post-apartheid, post-sanctioned), combined with poor [national and institutional] governance and a struggling economy, exacerbated the existing disparity between 'rich' and 'poor' South African universities (MacGregor, 2008).

Unfortunately, the need to generate external income also gave [local and international] industry an opportunity to fund research, often considered unethical in the Western world, especially in the field of HIV (Carome, 2017). The evidence seems to suggest that, for example, manufacturing as well as other industries have moved from Western countries to poor countries, in search of cheap labour, lower tariffs, fewer stringent environmental protection laws, and more flexible government policies (Howard-Hassmann, 2005). As Parenti (1978:60) argues, "the corporation's social responsibility is nothing more than to itself, to its own system of production and accumulation".

From an institutional management point of view, the renewal process of HEls was mainly perceived as an opportunity and desire to join the 'Global Project'. At this point in time, it is important to be reminded that local HEls also had to recover from the international sanctions against the apartheid regime. Sanctions placed many restrictions on efforts for globalisation during the apartheid era. In effect, with the introduction of democracy, the world opened its doors to South Africa. Driven by both the 'Global Project' and a concomitant dramatic change in political environment, universities were afforded the freedom to significantly restructure their management models. Tertiary education is big business, so many institutions modelled their management on multinational corporations. Within this context, several local vice chancellors became CEOs, Deans became Directors, students became clients, staff were treated as an asset, and productivity as intellectual property. 'Trade creep' in the thinking of a globalised education system, is inevitable. The "whole experience of HEls, all the assessors, the amenities, the aura, has been commercialised...” (Twitchell, 2004:50).

Globalisation is a word with extraordinary currency (Apple, 2011:222). The concept of globalisation eventually moved into the formal arena of national policy, especially where transformation and restructuring are concerned. The South African Council for Higher Education (CHE) argued in favour of restructuring guided by globalised conditions. Firstly, the $\mathrm{CHE}$ accentuated the concern to "develop the thinking and intellectual capacities of 
our society", which is believed to be central to economic, social, cultural and political stability (CHE, 2000b). Within the neoliberal era of minimum state regulation and the sudden triumph of a global marketplace marked by free trade, especially after years of political and economic isolation, people believed that a degree qualification - possessed by "those with a larger repertoire of skills and a greater capacity for learning" - offers a means of gaining "unprecedented fulfilment" in the job market (CHE, 2000b). Also, the image of success was 'romanticised' by Hollywood, after a flood of television series introduced this sentiment into the minds of our youth. It portrayed glamour, wealth, power, success and influence as part of the lives of those equipped with a university degree. Unfortunately, these themes also redirected many students towards very limited, but sometimes at the expense of 'less attractive', but equally vital to society, areas of study. Aronowitz and Giroux (2000:333) acknowledged that "colleges and universities are perceived - and perceive themselves - as training grounds for corporate berths".

\section{Globalisation, democracy and social stability}

It is apparent that the development of a work force guided by a need for a competent and trained society is primary to South Africa's ability to, with purpose, energy and creativity, create a just environment after years of apartheid and suppression. This ideal is aligned with the logic of globalisation which demands investing in a labour force that creates a foundation for a just environment and requires structural assistance for the same reason. This, however, necessarily relies on the assumption that social stability can be achieved as a result or consequence, whether direct or indirect, of competing globally. The South African Council for Higher Education (CHE) publicly confirms their acceptance of this association by stating their commitment to the creation of a structure that envisages fairness and pursues greatness as inherent to the building of a just nation. It commits itself to achieving significant development in the quality of institutional practices. The $\mathrm{CHE}$ is familiar with the fact that the efficiency of the products of the system should be improved. Such an outcome requires of the inefficiency prevalent in the system to be confronted. This would dramatically improve the capacity for South African HEls to become globally more competitive (CHE, 2000b).

A reduction in inequality embraces the presumptions that provide the foundation for the CHE's reasoning for prioritising globalisation. It affirms that the $\mathrm{CHE}$ has assumed that its blueprint for improving quality of performance and managing HEls in an efficient and qualitative manner promises to guarantee international financial competitiveness and its direct relations with social justice (Jones, 1998). Overall, globalisation looks attractive from a socio-political point of view. In fact, in their study, Kauder and Potrafke (2015:367) came to a very firm conclusion that the policy implication of their results is that allowing the country markets to become internationally interweaved is compatible with and enhances social equity (see Figure 1). Globalisation, therefore, appears on the surface to hold the potential and build the necessary capacity to address the injustices of the past, a phenomenon which in this case is backed by "rational and objective [sic] scientific evidence" (Kauder \& Potrafke, 2015:353). 


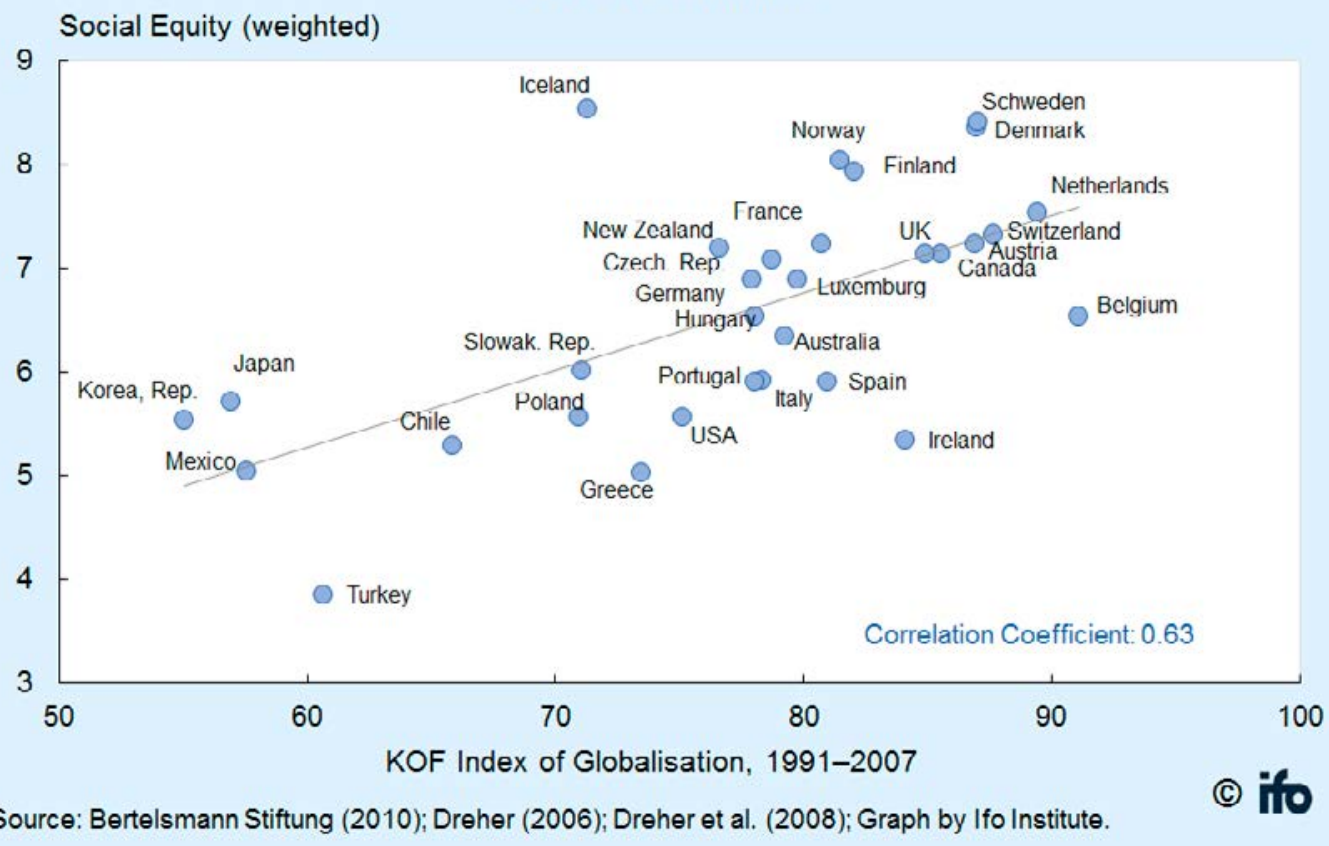

Figure 1: Social equity (weighted) and overall globalisation

The KOF Globalisation Index measures three main dimensions of globalisation: economic, social and political. KOF is an acronym for the German word 'Konjunkturforschungsstelle' meaning: Economic Cycle Research Institute. In addition to these three main indices, they also calculate an overall index of globalisation and sub-indices referring to: actual economic flows, economic restrictions, data on information flows, data on personal contact and data on cultural proximity. Data are available on a yearly basis for 207 countries as far back as 1970 .

\section{Globalisation and structural inequality and underdevelopment}

A second argument for transformation driven by global directives describes the concern for reducing elevated levels of 'structural inequality and underdevelopment' en route to achieving global competitiveness. Structural inequality is defined as a condition where one category of people is attributed an unequal status in relation to other categories of people (Dani \& De Haan, 2008:13). This relationship is perpetuated and reinforced by a confluence of unequal relations in roles, functions, decisions, rights and opportunities. As opposed to cultural inequality, which focuses on the individual decisions associated with these imbalances, structural inequality refers specifically to the biases that are systemically rooted in the normal operations of dominant social institutions and can be divided into categories like residential segregation or discrimination regarding access to healthcare, employment and educational opportunities (Royce, 2009:216). 
As in the United States (Liao, 2009), structural inequality is still believed to be an embedded part of the culture of South Africa due to the history of apartheid and the subsequent suppression of equal civil rights of non-Caucasian races. Structural inequality has been encouraged and maintained in the society of South Africa through structured institutions such as the public-school system with the goal of maintaining the existing structure of wealth, employment opportunities and social standing of the races by keeping students of colour from high academic achievement in high school and university as well as in the workforce of the country. Not only the classes that students take, but also the primary and secondary school they were enrolled in have been shown to influence their educational success and social mobility, especially their ability to graduate from university. Simply being enrolled in a school with less access to resources makes one much less likely to gain access to a university.

Globalisation has a complex association with development and inequality, and mandates a new framework to help describe its effects. On one level, global competition can lead to productivity improvements that lead to a situation where employment falls behind output in a local market. This can have an enormous impact on developing economies that focus on industrialisation. Combating structural inequality often requires a broad, policy-based structural change on behalf of government institutions, and is often a critical component of poverty reduction. In many ways, a well-organised democratic government that can effectively combine moderate growth with redistributive policies stands the best chance of combating structural inequality (Collier, 2007:31). Much of the research on the link between globalisation and inequality has focused on the global scale - looking at inequality between countries using aggregate economic indicators such as gross domestic product per capita (sometimes weighted by national population). These measures of global inequality are limited because they implicitly assume that withincountry distributions of income are perfectly equal (Milanovic, 2005:30). Comparisons of inequality across individuals in the global population, and across a broader range of measures, regardless of national boundaries, are much rarer, but are increasingly possible and necessary (Milanovic, 2005:31). Beyond the need for improved measures of global inequality, we are currently witnessing a historic change in patterns of inequality, termed by Firebaugh and Goesling (2004:288) as the "inequality transition". Since the 1980s, evidence suggests that inequalities have increased more rapidly within countries than between them, heralding the reversal of increasing between-country inequality a trend that began with the Industrial Revolution (Milanovic, 2005:37).

Because it may seem illogical that inequality between independent communities in a larger population would grow in an era of globalisation, this finding points to the importance of research on relative differences in inequality patterns, and on the impacts of specific aspects of economic globalisation, so that we can better understand how globalising processes influence inequality - where and for whom (Kanbur \& Venables, 2007:210). Addressing this problem requires research aimed at identifying how distributional mechanisms within markets and governance arrangements are shaping inequality across country borders and differentially distributed populations (Lobao et al., 2007:2). The timing of the recent shift in inequality patterns (the early 1980s) corresponds with the rise of 
new forms of economic globalisation that have transformed spatial relationships around the globe. Expanding transportation and communication networks, trade freedom, reorganisation of financial structures, and the rise of new regional trade agreements have been redefining flows of commodities, investments, labour, and political power across the globe (Dicken, 2007:228). In the process, the "who gets what?" of the winners and losers of globalisation is changing, as is the traditional role of the state in financial regulation. The government is no longer the exclusive actor in economic processes because markets have become global, regional, and local as much as they are national.

\section{Social justice}

In the West and older Asian societies, the concept of a just society has often been understood as the process of making sure that each citizen plays a societal role and receives some form of reward for their role in society. In the current article, the author rather supports a different definition, which moves closer to the concept of true democracy, as defined by Dewey (1958:18), who explained that democracy is not exclusively the function of a body of institutions, or the public enterprise, but rather incorporates utilitarian ways of group expression and contributions made by each member of such a group. He explains that democracy results from the virtuous cause of the self-respect and values of the individual. Through respecting each other, tolerating one another, giving and taking and prioritising realistic experiences we finally discover the only way in which individuals can prosper in carrying on this test which all of us have to take, regardless of whether we acknowledge this or not. This is, of course, the ultimate test of mankind - that of sharing space in such a way that the lives of others become instantly profitable in a very deep sense, lucrative to each one of them, and supportive in the development of the livelihood of those around them (Dewey, 1958:21). Harper (1970:32) alludes to this form of democratic enterprise as having a very specific role to play in society, and that this role is of a very particular nature.

\subsection{Social justice and democracy}

HEls should be perceived as the seer of social justice, as well as its clergy and its philosopher; or, stated otherwise, HEls are the "Messiahs" of this enterprise and responsible for its delivery (Harkavy, 2006:6). Lee Bollinger (2003), president of Columbia University, recently commented that the primary function of universities is to satisfy "a spirited curiosity". This simplistic view stands in stark contrast to the proposition made by Karl Marx (1970:123) in his 11th lecture on Feuerbach, that HEls exist for real-world action-oriented problem-solving, and that the most significant, insatiable "human drive" is not being inquisitive about our environment, but instead the inherent materialistic needs - and as a consequence, desire - to improve it; to construct and sustain the "Good Society" in which members of that society live long, active, peaceful, productive, happy lives (Marx, 1970:123). Currently, democracy is left in complete chaos. It has become increasingly evident that the modern nation-state is just a grouping of economic and 
political multinationals at the service of their own interest (Esteva \& Prakash, 2014:16). This can be classified as a pseudo-democracy, or some form of democratic despotism.

In the current international public outcry for democracy, one should use caution not to confuse it with a communist movement. Instead, the emphasis is on removing hurdles that prevent social mobility, the creation of buffers that guard against social and monetary insecurity, etc. (adopted from Fultz, 2012; Kitching, 2012:27). A just society assigns rights and responsibilities to people, which gifts everyone with the benefits (and burdens) of being part of that bigger society. The kind of contributions can vary, but most often come in the form of taxes, social grants, tertiary education, public health, basic education, primary health care, labour laws and regulation of trade, etc. The aim is to promote fair distribution of wealth, and equal opportunity.

In A theory of justice, John Rawls (2005:20) explained social justice as an agreement made behind a screen of innocence, because the role of each member within the society is not yet known. Everyone thus decides from an impartial outlook. Rawls (2005:73) perceives equality as a far-reaching primary freedom aligned with a similar freedom for others. He defines the outcomes to be of the most benefit to the disadvantaged individuals within a group, while opportunities exist for every individual within a just and equal environment (Rawls, 2005:76). Rawls therefore includes the procedure and distribution of social justice.

Authors such as Robert Nozick (2013) take a more liberal view of social justice, attempting to consolidate social justice and modern market-driven ideologies. Perceiving it as a natural event, a "dominant protection agency" always appears, by means of discretionary agreements. This constitutes the minimal state. Nozick (2013:283) thus perceives an allocation as socially just based on sovereign and interactive exchange, regardless of whether large disparities might result. This is therefore a procedural justice.

Friedrich von Hayek explained that only justice of procedure can be achieved in an industry-driven monetary system (Von Hayek, 1973:234), which is not exactly the outcome we wish for in a country such as South Africa, unless we desire to uphold the status quo, with elevated levels of unemployment, income disparity, gender inequality, and old and new forms of discrimination. The issue is that a university could subscribe to democratic values, but not necessarily be an advocate of social justice, especially if it builds a system around arguments such as those posed by Nozick. Unfortunately, the harsh reality is that there exists a uniform agreement that it is possible to consolidate a market-driven mentality with the conflicting societal role HEls must play. This mentality has transcended through governments, regulatory bodies, societies, councils, universities, colleges, and finally, the programmes where it is installed into the mind of each individual learner, scoping the way through which he or she eventually approaches and perceives their mundane and professional role in broader society. 
HEls have promoted themselves in the public domain and justified public funding for their activities because they serve the interests of society (Lynch, 2006:4). HEls therefore have a primary responsibility to create opportunities for learners to reach their full potential, but during the process to develop an awareness of social responsibility, learning to participate in a just society and promote change that will embrace democracy and justice. We should utilise measures that assess justice in outcomes and procedures (Pendlebury \& Enslin, 2003:33). Even within the international context, this should serve as a primary mission of all HEls, including private universities. It seems, however, that in some instances HEls perceive their function in society to be fulfilled, based on the assumption that a degree should be able to "guarantee" personal monetary gains, which stimulate the economy, lead to job creation, etc. These institutions neglect public gains which, in a broader context, should benefit all of society (Brennan \& Naidoo, 2008:289). The impact on society is not only an essential moral quality of the broader society but eventually determines the collective value of the entire social system.

HEls can in many ways be compared to big companies. The issue of social justice should also be promoted within its own structures and systems. It educates and promotes the concepts of equity, democracy, fairness, etc. which eventually aid in fostering awareness of these qualities in the public sector; and, for its own part, it must embrace and support procedural justice (Harkavy, 2006:10). That should be where we start the process. HEls must be aware of various aspects of equality among both their employees and learners, provide facilities to those with a disability and, in general, promote social justice within their own structures (Brennan \& Naidoo, 2008:288). They should, beyond this, perceive themselves as the creators and guardians of intellectual property produced for the greater good of society at large (Lynch, 2006:4). They are the watchdogs for the free exchange of knowledge in a free and just society. They should function to guard freedom of thought, including the freedom to differ from the 'common sense' of our time.

\subsection{The example of engineering education and its contribution to social justice}

Engineering as a profession serves as an excellent example of how social justice can be promoted within our academic offerings. In the case of engineering degree programmes, national accreditation bodies prescribe the contents of the curriculum. Eventually, it is also the social construct of these accreditation bodies that permeate our programmes. Their values and principles become ingrained in the minds of our students who enter the industry, carrying these values over to those they work with, employ, their families, and eventually spreading them through society. The way in which these accreditation boards word their definition of engineering, in itself, provides good insight into how we academically guide our students: 


\subsubsection{The United Kingdom's (UK) Royal Academy of Engineering}

The UK defines Engineering programmes based on four vital challenges. Three of these challenges are reflexive (improved engineering leadership, training and public recognition of engineers) whereas the fourth, "Drive faster and more balanced economic growth", refers to social justice, by means of promoting corporate interests "to improve the capacity of UK entrepreneurs and enterprises to create innovative products and services, increase wealth and employment and rebalance the economy in favour of productive industry" (Royal Academy of Engineering, 2012).

\subsubsection{Accreditation Board for Engineering and Technology (ABET)}

ABET, which is the biggest international non-governmental organisation that accredits 3709 engineering programmes, distributed over 752 universities and colleges in 30 countries, defines an engineer as an expert with "knowledge of the mathematical and natural sciences gained by formal learning, experience, and practice is applied with judgment to create ways to apply in a financially responsible manner the materials and forces of nature to the benefit of the livelihood of mankind" (https://en.wikipedia.org/ wiki/ABET).

\subsubsection{The Engineering Council of South Africa (ECSA)}

ECSA defines engineers as qualified professionals who practise science, engineering science, and technology with a focus on problem-solving of financial value and issues critical to the advancement of society. Problem-solving should rely on the basic sciences, mathematics and engineering knowledge. Solutions depend on the ability of the engineer to analyse and synthesise, using sound technical and financial principles as a guideline. Any solutions must consider the needs of societies, be sustainable and protect the physical environment (ECSA, 2017).

\subsubsection{The Canadian Engineering Accreditation Board}

The Canadian Engineering Accreditation Board defines an engineer as a professional required to be competent in engineering, as well as conceptualising the effect of their work on society. As a result, accredited engineering qualifications must contain sufficient mathematical, scientific and engineering education, in addition to the fact that they must also develop graduate attributes and an understanding of the impact of their work on the environment, culture, economy and society, and of the principles of developing in a sustainable manner.

The Canadian definition offers a completely different view. Some of these definitions of engineering can be analysed in a way that environment and society exist to be exploited. Some professionals therefore have reasoned that because of this approach, engineers have been appointed as "hired guns" to be utilised for political and financial gain. Unfortunately, it is a given that HEls aligned their engineering programmes with the appropriate regulatory body. The outcome in terms of who and what we produce because of this is self-evident. In a system that appropriately targets social justice as a component of its programmes, evaluation should be founded on the clear and implicit terms of how 
it delivers professionals and outcomes (education, research and community service) that assist in the dispensation of financial prosperity, improved individual livelihood and social equity.

Within the realm of social justice, HEls should necessarily add a space for measuring the relation of the institution itself and society. This is measured by the explicit and tacit terms for how it manages to deliver professionals and products (by research and through community service) that aid in the distribution of wealth, opportunities for personal activity and social privileges. In this paper, it was shown how social equity and levels of globalisation are assumed to be positively correlated (Figure 1) and that the one seems to strengthen the other. This seems like a highly convenient truth.

SA currently ranks 61st on the Globalisation Index. Yet, one needs to take a much closer look at the reliability and validity of Figure 1 to see how the outcome of the calculations objectively matches the real-time 'state of the nation': Smaller countries seem to be overrepresented at the top of the rankings, suggesting that there might be some bias in how the final values are calculated (distances to neighbouring countries are short, making it easier to engage in foreign travel, or there are few places to visit at home). Relevance of using international mail (used as part of the KOF calculation) seems low given the rise of email and the Internet. Trade in books and newspapers are falling in many places due to the rise of e-books and online news sites. Also, in some countries people may access books and newspapers through libraries. This is not reflected in the KOF data. 'Internet users' is based on people with access to the Internet, but how can this be established accurately if, in some countries, the community relies heavily on Internet cafés rather than home connections? Trade calculations often ignore the informal sector which can account for a substantial proportion of actual trade. Many countries have large numbers of illegal foreign migrants. They are not counted in the KOF. Some countries share diplomatic offices. This means that although they may have a presence in another country, the KOF index does not recognise this. Some countries choose to be neutral and do not participate in UN peacekeeping missions or other international organisations as a result. This does not mean they are less globalised than those that do. By publishing ranking, KOF seems to be implying that those at the top are 'better' than those at the bottom. This is not necessarily true as globalisation brings problems as well as benefits to countries. These factors all question this 'persistent positive link' that governments/institutions/ businesses claim to exist between the degree of globalisation and social justice.

The standard Heckscher-Ohlin model of international trade predicts that a country's relatively abundant factors gain, and a country's relatively scarce factors lose, from globalisation. In high-income countries, skilled workers should thus gain from the process, whereas unskilled workers should lose. Social injustice in consequence of globalisation should thus also be prevalent even in high-income countries (Hillman, 2008:175). Yet, the most affected are the less affluent countries.

Income equality is usually viewed as one of the most important determinants of social justice (Kauder \& Potrafke, 2015:355). Depending on the variable used to measure inequality, the time, and the dataset, South Africa's Gini coefficient ranges from about 
0.660 to 0.696 . The Gini coefficient is the measure of income inequality, ranging from 0 to 1 where 0 is a perfectly equal society and a value of 1 represents a perfectly unequal society. This would make South Africa one of the most consistently unequal countries in the world (Bhorat, 2015). The wealth of South Africa's top $10 \%$ of the financial elite has grown by $64 \%$ in the first 17 years after the fall of apartheid, while the poorest $10 \%$ have seen no financial growth whatsoever (Church, 2016). In 2017, and Oxfam Report (2017) showed that just eight individuals, all men, own as much wealth as the poorest half of the world's population, calling for action to curtail rewards for those at the top. As decision-makers and many of the super-rich gathered for the World Economic Forum (WEF) annual meeting in Davos, the charity's report suggests the wealth gap is wider than ever, with new data for China and India also indicating that the poorest half of the world owns less than previously estimated (Oxfam, 2017).

The number of social grants awarded to individuals in South Africa has increased exponentially over the past twenty years: from an estimated 4 million in 1994 to 17191121 by February 2017. The lack of household access to food is one of the biggest drivers of social grants (FACTSHEET: Social grants in South Africa - separating myth from reality, 2017). One should therefore expect substantial funding from public and private industry to be directed towards these basic but vital research issues that threaten the livelihood of the South African population (including nutrition, food security, agriculture, public health, etc). Yet, substantial reductions to the budgets of government agencies limited funding for most of these fields of study. The government budget remained relatively stagnant over recent years and was even subject to substantial budget cuts. Government has purposefully and steadily increased its funding for technology research and development over time, understanding that achieving substantive technical progress requires longterm government commitment. Naledi Pandor (2014), the then Minister of Science and Technology, publicly stated that the increased financial support to technology research is aligned with the National Development Plan (NDP) and should be perceived as an important message about government's commitment to improve the capacity of South Africa to compete globally.

The question arises as to why government would direct more funding towards research that is globally driven (such as technology development) but does not contain any value in terms of the needs of local communities. Also, career prospects for students who graduate with a degree in the social sciences is limited. This narrow view has had an especially negative impact on the humanities and social sciences departments at HEls, with some being downsized, others closed completely, and some merged with other departments for the sake of financial relevance and competitiveness (Waghid, 2001:457).

Within the context of social justice, the future looks bleak. One finds that the CHE (2000a) proposals for restructuring explicitly refer to "increasing capital- and knowledge-intensive production and services [which] have created a growing demand for skilled professionals in the scientific, technological, technical and business fields". The consequence is that the "availability of skills in the sciences and the technological, technical and business fields" is (being considered) as a precondition for (global) competitive success (CHE, 2000a), but 
that the issue of social justice is completely omitted from this statement. The negative impact globalisation exerts on domestic democratic institutions is not going to vanish soon. Education must not be confused with labour training. Educators should resist allowing commercial values to shape the purpose and mission of HEls. Already in 1952, Richard Hofstadter identified the danger of private enterprise mentalities within HEls, concluding that the most vital argument in favour of HEls should not be based on their service, but instead on the principles they depict. The values of justice, freedom, equality, and the rights of citizens as equal and free human beings are central to the role of educating students for the demands of leadership, social citizenship, and the democratic public sphere (Waghid, 2001:459).

Estimates of globalisation show that South Africa almost exponentially increased its international presence after the democratisation of the country in 1994 (Figure 2). Unfortunately, the extent of globalisation for local universities is difficult to measure and only open to speculation. If evidence such as that provided by Kauder and Potrafke (2015:360), who showed that to become globally integrated is consistent with and promotes social equity (Figure 1), one should expect that for South Africa, estimates of social equity should show a concomitant improvement. Historical data shows that South Africa has always had a high rate of unemployment, entering the 'top' 10 for the first time in 1997 with an unemployment rate of 22.9\%. More than three decades later, the unemployment rate in South Africa was 26.5\% in the last three months of 2016 after reaching a $12 \frac{1}{2}$-year high of $27.1 \%$ in the previous period. Within the context of social equity and/or democracy, it would be safe to conclude that globalisation has not emancipated the masses, at least not in South Africa. Government intervention that promotes globalisation as a vehicle for achieving equity, and how HEls respond to this call, have therefore failed the very people it was intended to benefit. Regardless of how insignificant this might seem, South Africa is not as happy as it used to be (Figure 3).

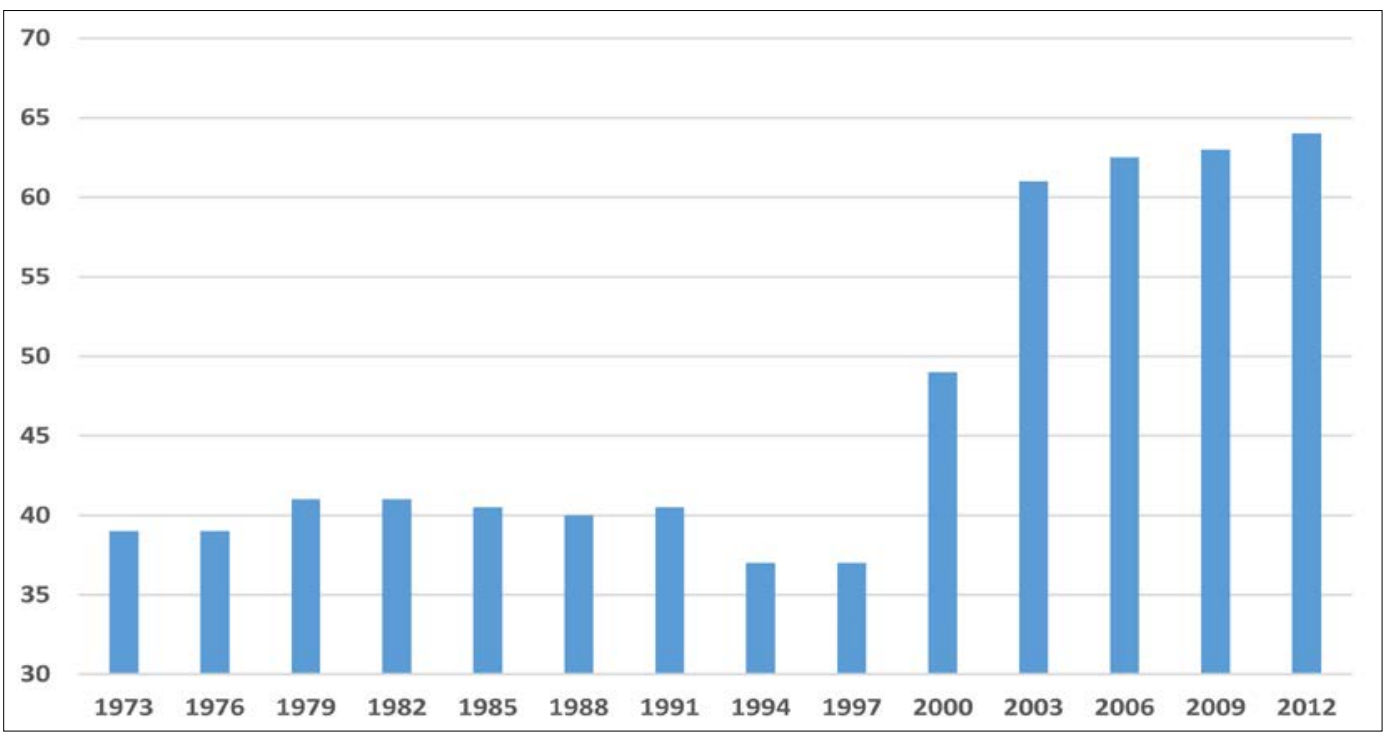

Figure 2: South Africa - overall globalisation

Source: Adapted from TheGlobalEconomy.com, The Swiss Institute of Technology in Zurich 


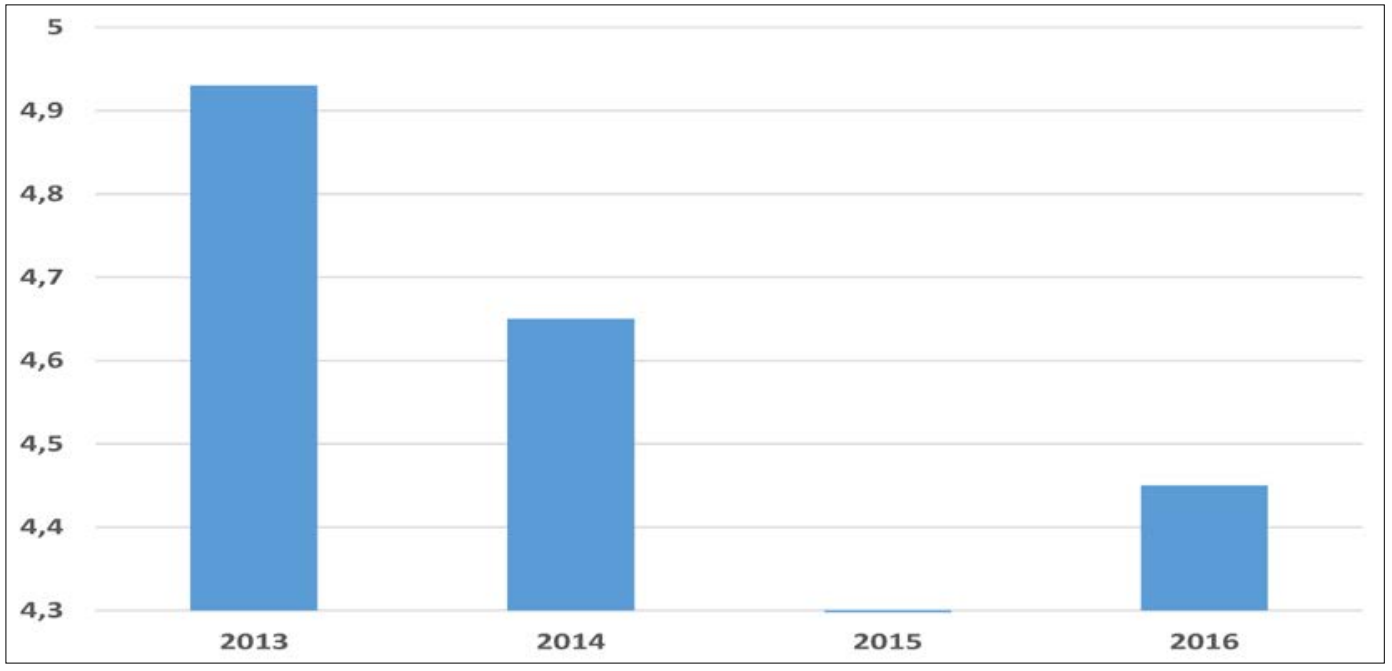

Figure 3: South Africa - happiness index

Source: Adapted from TheGlobalEconomy.com, The World Happiness Report

To step back and remove oneself from the implacable logic of a single-minded contemporary paradigm is to step out of the chains of an abstract temporality. Democracy and social justice cannot be boxed into any single category of globalisation, because social justice is multifactorial and relies on a complex interplay of everything that defines us as both isolated beings and collectively, as communities. Authors such as Sharon Gewirtz (1998:472) therefore argue that (social) justice has two inter-connected dimensions, one rational (individual) and the other distributional (social). Post-modern HEls approach social justice only from within a limited and fragmented framework. Eventually, the discussions within our academic programmes have become synonymous with discussions of how material and monetary resources are distributed in society (who gets what?). These discussions neglect social cohesion and equality beyond financial wealth. In the process, HEls jeopardise issues at an individual level, such as gender equality and human rights (Kauder \& Potrafke, 2015:360), but also broader community issues, such as the fear and threat of homogenisation of cultures (Back et al., 1996; Lingard \& Rizvi, 1998:63).

As a matter of convenience, it can be said that HEls have neglected their responsibility towards society, using the excuse that such business should be left to the politicians. Instead, HEls have become subordinated to the demands of the international market place, with a message that is being contradicted by its context. Considering that large sums of corporate capital flow are invested in HEls, efforts to transform them are directed according to imperatives of private industry. Power is handed over to big multinational companies (Waghid, 2001:458). Linked to this is the view that globalisation is the "direct consequence of the expansion of European cultures across the world via settlement, colonialization and cultural mimesis" (Yang, 2003:272). Other authors contend that globalisation is also seen as a form of specifically American cultural imperialism (Porter \& Vidovich, 2000). Statistics from the United States Department of Defence indicate that as far back as 1999 the US military already had troops in 135 countries (or $70 \%$ of the world's countries) (US Department of Defense, 1999). This is unprecedented in world 
history and it should be questioned whether this presence is in the name of democracy and to safeguard human rights. More broadly, globalisation is perceived by many as "Western cultural imperialism" (Porter \& Vidovich, 2000:45). This hegemony is considered a process of social control that is subtle in that it is not evident or even potentially under conscious control, but is carried out through the moral and intellectual leadership of a dominant socio-cultural group.

The most essential element is that this hegemonic sense is generated by the community who accept it as common sense (Baillie, 2012:41). Elite reproduction theorists perceive educational processes in terms of how they systematically prepare students for their differentiated future positions within a contemporary capitalist economy and social structure (Moore, 2004). This preserves inequality. It displays great power over "other cultures and is often seen as especially unfavourable to small and weak cultures". Since the costs of market-driven reforms may be imposed politically and economically on already "weakened social groups", that is, the poor and unemployed, socio-economic inequality is aggravated as a result (Im, 1996:280). This is a major barrier in achieving democracy, which cannot thrive in an environment where there exists serious socioeconomic inequality. The globalisation of HEls aims to produce "citizens that feel at home in the world", but where the process is driven by a combination of financial and educational motivations, it becomes almost impossible to achieve (Haigh, 2008:430), because the boundaries between institutional transformation and the imperatives of the market place have seemingly become blurred (Waghid, 2001:460). Real progress is being impeded by institutional management systems that prioritise financial sustainability as their model (Haigh, 2008:440). A very strong case can therefore be made against the ascendancy of market-driven global directives in defining the restructuring of HEls and its failure in creating a just 'global' society.

The perception of the university as a competitive (global) enterprise is countered with the public service model and the notion of "higher education as a public good" (Olsen, 2007:30; Van Vught, Van der Wende \& Westerheijden, 2002:105). Previously, there was a reluctance to invest in HEls in developing nations, which were seen to serve only the local elites. Higher education is not mentioned by the Declaration of the World Conference on Sustainable Development or the UN Millennium Development Goals (WSSD, 2002; UN, 2005). Preserving the underdevelopment of HEls in low-income countries both motivates international student migration and fuels a 'brain drain' that supports the hegemony of the West; they can pick the 'best performing products' and send the rest home (Task Force on Higher Education and Society, 2000).

Also, more research indicates that high- and middle-income countries benefit from globalisation whereas low-income countries do not gain from it. In 2003, it was estimated, however, that over 1.2 billion people in the world (or approximately $20 \%$ of the world population) must live on the equivalent of less than one US dollar a day. The issue is that the number of poor households is increasing at a much higher rate than the well-to-do household (United Nations, 2003). Overall poverty rates, however, have declined in all regions, even though progress has been uneven: half of the extreme poor 
live in Sub-Saharan Africa. The number of poor in the region fell only by 4 million with 389 million people living on less than US\$1.90 a day in 2013 - more than all the other regions combined (The World Bank, 2016). Birdsall (2002:70) concluded that globalisation is fundamentally asymmetric for poor countries because their economic structure and markets are asymmetric. The risks of globalisation hurt the poor more. The structure of the export of low-income countries depends heavily on primary commodity and natural resource which make them vulnerable to global shocks (Samimi \& Jenatabadi, 2014). Ironically, the international agencies that promote planetary citizenship also encouraged belief in or reliance on academic or other formal qualifications as the best measure of a person's intelligence or ability to do a job (Bloom, 2003).

Some sceptics reason that the era of globalisation has come to an end (Gray, 2009:7). These authors consider globalisation as a fruitless exercise and conclude that it was highly idealistic. Kauder and Potrafke (2015:365) reason that the problem is not with globalisation itself, but rather in the way it has been managed. HEls have developed a mentality not to question the benefit of market-driven education but to blame the mishaps on those responsible for its implementation. There seems to be a 'general' agreement that global multilateral frameworks and contracts of collaboration have not delivered the desired outcomes (Gray, 2009:11). This is true even outside the realm of tertiary education, with the recent withdrawal of Britain from the European Union (Brexit) serving as a good example. Several global role-players can therefore be perceived as having withdrawn from the 'Global Project', in an environment where regional and national conflicts have drawn us back into an era that simulates that of the 'Cold War', with controlled travel and barriers to migration, financial isolation, etc. Most of us are disillusioned with contemporary society and how the economic drivers and dominant discourse necessarily lead us to selfish, point-gaining competitive behaviour.

In 2016, South African HEls were hit with major student protests, coined \#FeesMustFall, which began in mid-October 2015 in response to an increase in tuition fees. Protests started at the University of Witwatersrand and spread to the University of Cape Town and Rhodes University before rapidly spreading to other universities across the country, causing massive destruction to public property and violent clashes between students and law authorities. By October 2016, the Department of Higher Education estimated that the total cost in property damage due to the protest since 2015 had amounted to R600 million (equivalent to US\$44.25 million). Even though the focus of the protests was on a rise in fees, several other factors formed the background for the protests. Lack of funding for poorer students to attend university, high incomes for university managers, lack of student housing, a real decline in government funding for HEls, lack of social transformation, to broader socio-economic, racial and even gender inequality issues were the main drivers of this campaign. Tension is created as soon as the 'goals' of a university do not match the needs of society. The author of this paper views \#FeesMustFall as the most concrete evidence that HEls in South Africa have neglected their role in creating a just society - not only by failing to address issues of social justice within their teaching programmes, but also by failing to respond in a socially just manner to their students, 
and on a much broader scale, the youth of South Africa. Within a system that is marketdriven, combined with the consequences of the \#FeesMustFall campaign, South African HEls face a major crisis, which will not be solved unless institutions imbed more socially sensitive principles into the system.

\section{Conclusion}

Globalisation is a new phenomenon causing global transformation and an extension of the chronic process of modernity. By some, it is considered as both a sought-after illusion and a dreaded evil. Yet, whatever it is, it is clearly the hegemonic discourse of the late twentieth and early twenty-first centuries (Porter \& Vidovich, 2000:464). Unfortunately, the global system and dependency perspectives suggest that the structure of the economy creates widening international disparity. Transformation of political and monetary systems have been hampered by those who believe that globalisation provides an amicable solution to the inequalities of the world. Neo-liberal contenders insist that globalisation in a capitalist socio-political environment promotes social justice. This statement is supported by a body of research that suggests that global inequality is being flattened, the North-South, core periphery, rich country-poor country divide is being destroyed as globalisation progresses (Wade, 2004:568).

From those who contend that poor countries are closing the gap between themselves and developed countries, one should be able to deduce that poor countries should 'theoretically' have faster growth as they exploit the returns to closing the productivity gap (Barro \& Sala-I-Martin, 1995), which is contradicted by current and forecasted state of the nation reports. Historically, through colonisation and exploitation, Western countries enriched themselves (Mahutga, 2006:1864) and concomitantly retarded the growth of poorer states by forcing them onto political and social paths that made technological advancement and competition with the core difficult if not impossible (Wallerstein, 1974:388). HEls did not leave this process unscathed, even though they function in an environment where there exists an expectation that they contribute towards a country's competitive edge in the global marketplace by producing intellectual property, perceived as a commodity of high value. There are those who contend that market competition within and between HEls, will create more efficient and effective institutions, and that management principles derived from the private sector which monitor, measure, compare and judge professional activities, will enhance how HEls are functioning (Naidoo, Sankar \& Veer, 2011:1146). Yet, the increasing demand for HEls to be managed as a global business has happened at the expense of its social contract. This consumerist turn in HEls has been aligned with policy discourses of distrust through which professional groups in the public sector are positioned as selfish opponents of change who are perceived to work against the interests of other stakeholders (Naidoo, Sankar \& Veer, 2011:1146). As a result, we need to question how much freedom exists within management of HEls when it comes to 'thinking new thoughts' or being creative or transformative. How does change come about and what costs are involved for those who would initiate it? To 'swim against the stream' in any thought field is a risky and costly business. 
HEls occupy space and time - it is a space of poaching and hidden territories; thus, there are many 'other spaces' that institutional management could profitably explore, develop and utilise. This activity, however, should take place under the umbrella of social justice, taking into consideration issues such as faith, tradition, culture, ethnicity, human rights to ecology and critical theories, such as feminism and the intersection of race, law, and power. Even though social justice as a term is ill defined, each of us knows what we mean by it. A simple approach in terms of transforming our HEls, would follow a formal route, first, to break down prevailing 'common sense' followed by a constructive process in which innovative ways of management are introduced. The historical conjuncture is ultimately a performative space elaborated among multiple planes, diverse trajectories, and unpredictable depths, but a path worth walking!

"Democracy is dead. Long live democracy! Our dreams don't fit into your ballot box!"

(Indignados, Spain)

\section{Acknowledgements}

The author wishes to thank the staff of the professional Doctorate in Business Administration (Higher Education Management) at the University of Bath (United Kingdom), the Department of Higher Education and Training (South Africa) for financial support, Professor Cheryl Foxcroft and her team at the Nelson Mandela University, and the University of KwaZulu-Natal for their ongoing support.

\section{References}

ABET (Accreditation Board for Engineering and Technology) (2017). https://en.wikipedia.org/wiki/ABET [Accessed 3 April 2017].

Apple, M.W. (2011). Global crises, social justice, and teacher education. Journal of Teacher Education, 62(2):222-234. https://doi.org/10.1177/0022487110385428

Aronowitz, S. \& Giroux, H.A. (2000). The corporate university and the politics of education. The Educational Forum, 64(4):332-339. https://doi.org/10.1080/00131720008984778

Back, K.J.C., Davis, D.V. \& Olsen, A. (1996). Internationalisation and higher education: Goals and strategies. Canberra: IDP Education Australia, Evaluations and Investigations Programmes Higher Education Division, Department of Employment, Education, Training and Youth Affairs.

Baillie, C., Kabo, J. \& Reader, J. (2012). Heterotopia: Alternative pathways to social justice. United Kingdom: John Hunt Publishing Ltd.

Barro, R.J. \& Sala-I-Martin, X. (1995). Technological diffusion, convergence, and growth. NBER Working Papers 5151, National Bureau of Economic Research Inc.

Bertelsmann Stiftung (2010). Soziale Gerechtigkeit in der OECD - Wo steht Deutschland? Sustainable governance Indicators 2011. Gütersloh. http://www.sgi-network.org [Accessed 10 April 2017].

Bhorat, H. (2015). FactCheck: Is South Africa the most unequal society in the world? The Conversation, 30 September 2015, 6.43am SAST. http://theconversation.com/factcheck-is-south-africa-the-mostunequal-society-in-the-world-48334 [Accessed 15 April 2017].

Birdsall, N. (2002). A stormy day on an open field: asymmetry and convergence in the global economy. In: D. Gruen, T. O’Brien \& J. Lawson (eds.). Globalisation, living standards and inequality. Sydney: Reserve Bank of Australia, Australian Treasury. 66-78. 
Bloom, D.E. (2003). Mastering Globalization: From Ideas to Action on Higher Education Reform. In: G. Breton, \& M. Lambert (eds.). Universities and globalisation: private linkages - public trust. UNESCO, IAU and Presses de l'Université Laval.

Bok, D. (2003). Universities in the Marketplace: The Commercialization of Higher Education. Princeton, N.J.: Princeton University Press. 256.

Bollinger, L.C. (2003). The idea of a university. Wall Street Journal, 15 October:15.

Brennan, J. \& Naidoo, R. (2008). Higher education and the achievement (and/or prevention) of equity and social justice. Higher Education, 56(3):287-302. https://doi.org/10.1007/s10734-008-9127-3

Buchan, N.R., Grimalda, G., Wilson, R., Brewer, M., Fatas, E. \& Foddy, M. (2009). Globalization and human cooperation. Proceedings of the National Academy of Sciences, 106(11):4138-4142. https://doi.org/10.1073/ pnas.0809522106

Burbules, N. \& Torres, C.A. (2000). Education and globalization: Critical analysis. New York: Routledge.

Carome, M. (2017). Unethical Clinical Trials Still Being Conducted in Developing Countries. TheHuffingtonPost.com, Inc. http://www.huffingtonpost.com/michael-carome-md/unethical-clinicaltrials_b_5927660.html [Accessed 15 May 2017].

CHE (Council for Higher Education) (2000a). Towards a new higher education landscape: meeting equity, quality and social development imperatives of South Africa in the 21st Century. Pretoria: Department of Education. 1-48.

CHE (Council for Higher Education) (2000b). Size and shape task team discussion document. Pretoria: Department of Education. 1-9.

Church, P. (2016). Economic inequality in SA "exploded after end of apartheid". The South African. http:// www.thesouthafrican.com/economic-inequality-in-sa-exploded-after-end-of-apartheid/ [Accessed 11 April 2017].

Collier, P. (2007). The Bottom Billion: Why the Poorest Countries are Failing and What Can Be Done About It. Oxford: Oxford University Press.

Country Paper: South Africa (2000). Education for a Global Era: Challenges to Equity, Opportunities for Diversity. Globalisation, Values and HIV/AIDS. 14th Conference of Commonwealth ministers, Halifax, Nova Scotia, Canada (27-30 November 2000). Pretoria: Department of Education.

Dani, A.A. \& De Haan, A. (2008). Social policy in a development context: structural inequalities and inclusive institutions. In: A.A. Dani \& A. De Haan (eds.). Inclusive States: Social policy and structural inequalities. Washington: The World Bank. 1-36. https://doi.org/10.1596/978-0-8213-6999-9

Dewey, J. (1958). Philosophy of education. Littlefield: Adams.

DHET, 2016. Report on the evaluation of the 2014 universities' research outputs. Department of Higher Education and Training, Pretoria.

Dicken, P. (2007). Global shift: Mapping the changing contours of the world economy. London: SAGE.

Dreher, A. (2006). Does globalization affect growth? Evidence from a new index of globalization. Applied Economics, 38:1091-1110. https://doi.org/10.1080/00036840500392078

Dreher, A., Sturm, J.E. \& Ursprung, H.W. (2008). The impact of globalization on the composition of government expenditures: Evidence from panel data. Public Choice, 134:263-292. https://doi.org/10.1007/s11127-0079223-4

ECSA (The Engineering Council of South Africa) (2017). https://www.ecsa.co.za/engineeringsa/SitePages/ What\%20is\%20Engineering.aspx [Accessed 03 April 2017].

Enders, J. (2014). The academic arms race: International rankings and global competition for worldclass universities. In: A.M. Pettigrew, E. Cornuel \& U. Hommel (eds.). The institutional development of business schools. Oxford: Oxford University Press. 155-175. https://doi.org/10.1093/acprof:oso/ 9780198713364.003.0007

Esteva, G. \& Prakash, M.S. (2014). Grassroots post-modernism: Remaking the soil of cultures. New York: Palgrave Macmillan. 
FACTSHEET: Social grants in South Africa - separating myth from reality, 2017. https://africacheck.org/ factsheets/separating-myth-from-reality-a-guide-to-social-grants-in-south-africa/ [Accessed 4 April 2017].

Firebaugh, G. \& Goesling, B. (2004). Accounting for the recent decline in global income inequality. American Journal of Sociology, 110(2):283-312. https://doi.org/10.1086/421541

Fultz, M. (2012). Bibliography of Books and Articles Published in English on Colonialism and Imperialism in 2011. Journal of Colonialism and Colonial History, 13(2). https://doi.org/10.1353/cch.2012.0017

Gewirtz, S. (1998). Conceptualizing social justice in education: Mapping the territory. Journal of Education Policy, 13(4):469-484. https://doi.org/10.1080/0268093980130402

Govender, T. (2013). The education gap - Practical solutions to key barriers. University World News, Issue No. 268. http://www.universityworldnews.com/article.php?story=20130419125136707 [Accessed 25 April 2017].

Gray, J. (2009). False dawn: The delusions of global capitalism. 2nd revised edition. London: Granta Books.

Haigh, M. (2008). Internationalisation, planetary citizenship and Higher Education Inc. Compare, 38(4): 427-440. https://doi.org/10.1080/03057920701582731

Harkavy, I. (2006). The role of universities in advancing citizenship and social justice in the 21st century. Education, citizenship and social justice, 1(1):5-37. https://doi.org/10.1177/1746197906060711

Harper, W.R. (1905). The university and democracy. In: W.R. Harper (ed.). The Trend in Higher Education. Chicago, I.L.: University of Chicago Press. 19-20.

Held, D., McGrew, A., Goldblatt, D. \& Perraton, J. (2000). Global Transformations: Politics, Economics and Culture. In: C. Pierson \& S. Tormey (eds.). Politics at the Edge. Political Studies Association Yearbook Series. London: Palgrave Macmillan. https://doi.org/10.1057/9780333981689_2

Hemsley-Brown, J. \& Oplatka, I. (2006). Universities in a competitive global marketplace: A systematic review of the literature on higher education marketing. International Journal of Public Sector Management, 19(4): 316-338. https://doi.org/10.1108/09513550610669176

HESA (Higher Education South Africa) Task Team (2008). Tuition Fees: Higher Education Institution in South Africa. http://www.justice.gov.za/commissions/FeesHET/docs/2008-HESA-Report-TuitionFeesInSA.pdf [Accessed 19 July 2017].

Higher Education in the Twenty-First Century: Vision and Action (1998). World declaration on higher education for the twenty-first century: Vision and action. http://www.unesco.org/education/educprog/ wche/declaration_eng.htm\#worlddeclaration

Hillman, A.L. (2008). Globalization and social justice. The Singapore Economic Review, 53(02):173-189. https:// doi.org/10.1142/S0217590808002896

Hofstadter, R. \& Hardy, C.D. (1952). The development and scope of higher education in the United States. New York: Columbia University Press. 11.

Howard-Hassmann, R.E. (2005). The Second Great Transformation: Human Rights Leapfrogging in the Era of Globalization. Human Rights Quarterly, 27(1):1-40. https://doi.org/10.1353/hrq.2005.0006

Im, H.B. (1996). Globalisation and democratisation: Boon companions or strange bedfellows? Australian Journal of International Affairs, 50(3):279-291. https://doi.org/10.1080/10357719608445187

Jones, P.W. (1998). Globalisation and internationalism: Democratic prospects for world education. Comparative Education, 34(2):143-155. https://doi.org/10.1080/03050069828243

Kanbur, R. \& Venables, A.J. (2007). Spatial disparities and economic development. In: D. Held \& A. Kaya (eds.). Global Inequality. London: Polity Press. 204-215.

Kauder, B. \& Potrafke, N. (2015). Globalization and social justice in OECD countries. Review of World Economics, 151(2):353-376. https://doi.org/10.1007/s10290-015-0213-1

Kitching, G. (2010). Seeking social justice through globalization: Escaping a nationalist perspective. Penn State Press.

Liao, T.F. (2009). Conceptualizing and measuring structural inequality. Center for Research on Inequalities and the Life Course. University of Illinois, Urbana-Champaign. Yale University. 
Lingard, B. \& Rizvi, F. (1998). Globalisation and the Fear of Homogenisation in Education. Change: Transformations in Education, 1(1):62-71.

Lobao, L.M., Hooks, G. \& Tickamyer, A.R. (eds.). (2007). The sociology of spatial inequality. State University of New York Press.

Lynch, K. (2006). Neo-liberalism and marketisation: The implications for higher education. European Educational Research Journal, 5(1):1-17. https://doi.org/10.2304/eerj.2006.5.1.1

Maassen, P. \& Cloete, N. (2006). Global reform trends in Higher Education. In: N. Cloete, P. Maassen, R. Fehnel, T. Moja, T. Gibbon \& H. Perold (eds.). Transformation in higher education: Global pressures and local realities. Netherlands: Springer. 7-34. https://doi.org/10.1007/1-4020-4006-7_2

MacGregor, K. (2008). South Africa: Third stream income a new priority. University World News, Issue No. 32. http://www.universityworldnews.com/article.php?story=2008061309381763 [Accessed 30 May 2017].

MacGregor, K. (2012). Plan for 1.5 million students by 2030. University World News 2007-2014. http://www. universityworldnews.com/article.php?story=20120115093819516 [Accessed 7 April 2017].

Mahutga, M.C. (2006). The Persistence of Structural Inequality?: A Network Analysis of International Trade, 1965-2000. Social Forces, 84(4):1863-1889. https://doi.org/10.1353/sof.2006.0098

Marginson, S. \& Van der Wende, M. (2007). Globalisation and Higher Education. OECD Education Working Papers, No. 8. OECD Publishing (NJ1).

Marx, K. (1970). Theses on Feuerbach. In: C.J. Arthur (ed.). The German Ideology. New York: International Publishers.

Milanovic, B. (2005). Can we discern the effect of globalization on income distribution? Evidence from household surveys. The World Bank Economic Review, 19(1):21-44. https://doi.org/10.1093/wber/lhi003

Moore, R. (2004). Education and society: Issues and explanations in the sociology of education. Cambridge: Polity.

Naidoo, R. (2003). Repositioning higher education as a global commodity: Opportunities and challenges for future sociology of education work. British Journal of Sociology of Education, 24(2):249-259. https://doi. org/10.1080/01425690301902

Naidoo, R. (2004). Fields and institutional strategy: Bourdieu on the relationship between higher education, inequality and society. British Journal of Sociology of Education, 25(4):457-471. https://doi. org/10.1080/0142569042000236952

Naidoo, R., Shankar, A. \& Veer, E. (2011). The consumerist turn in higher education: Policy aspirations and outcomes. Journal of Marketing Management, 27(11-12):1142-1162. https://doi.org/10.1080/026725 7X.2011.609135

Nozick, R. (2013). Anarchy, state, and utopia. New York City: Basic Books.

Olsen, J.P. (2007). The institutional dynamics of the European university. In: P. Maassen \& J.P. Olsen (eds.). University dynamics and European integration. Netherlands: Springer. 25-54. https://doi.org/10.1007/9781-4020-5971-1_2

Oxfam (2017). Just 8 men own same wealth as half the world. https://www.oxfam.org/en/pressroom/press releases/2017-01-16/just-8-men-own-same-wealth-half-world [Accessed 11 April 2017].

Pandor, N. (2014). Minister Naledi Pandor on 2012/13 Research and Experimental Development Survey results. http://www.gov.za/media-statement-minister-science-and-technology-naledi-pandor-mp-regarding201213-research-and [Accessed 15 April 2017].

Parenti, M. (1978). Power and the Powerless. New York City: St. Martin Press.

Peters, M.A. \& Humes, W. (2003). Educational futures: Utopias and heterotopias. Policy Futures in Education, 1(3):428-439. https://doi.org/10.2304/pfie.2003.1.3.1

Pendlebury, P. (2004). Social justice and inclusion in education and politics: the South African case. Journal of Education, 34(1):31-50.

Pettinger, P. (2007). Does Globalisation benefit both developed and developing countries? http://econ. economicshelp.org/2007/05/discuss-whether-globalisation-benefits.html [Accessed 19 March 2017]. 
Porter, P. \& Vidovich, L. (2000). Globalization and higher education policy. Educational Theory, 50(4):449-465. https://doi.org/10.1111/j.1741-5446.2000.00449.x

Rawls, J. (2005). A theory of justice. Cambridge, M.A.: Harvard University Press.

Royce, E. (2015). Poverty and power: The problem of structural inequality. 2nd edition. Lanham Maryland: Rowman and Littlefield.

Samimi, P. \& Jenatabadi, H.S. (2014). Globalization and economic growth: Empirical evidence on the role of complementarities. PloS one, 9(4):p.e87824. https://doi.org/10.1371/journal.pone.0087824

Scott, P. (1998). Massification, internationalization and globalization. In: P. Scott (ed.). The globalization of higher education. Buckingham: The Society for Research into Higher Education/Open University Press. 108-129.

Subotzky, G. (1999). Complementing the marketization of higher education: knowledge production for social development in community-higher education partnerships. In workshop titled 'New Knowledge Production - Interrogating the Gibbons Thesis from the South African Perspective'. Education Policy Unit, University of Western Cape (Vol. 27).

Task Force on Higher Education and Society. (2000). Peril and Promise: higher education in developing countries. Washington, D.C.: Task Force on Higher Education and Society/International Bank for Reconstruction and Development.

The Royal Academy of Engineering (2012). https://www.raeng.org.uk/

The World Bank (2016). Understanding Poverty. http://www.worldbank.org/en/topic/poverty/overview [Accessed 30 May 2017].

Twitchell, J.B. (2004). Higher Ed, Inc. The Wilson Quarterly (1976-), 28(3):46-59.

United Nations Development Programme (Thailand) (2003). Thailand Human Development Report.

Van der Wende, M. (2007). Internationalization of higher education in the OECD countries: Challenges and opportunities for the coming decade. Journal of Studies in International Education, 11(3-4):274-289. https://doi.org/10.1177/1028315307303543

Van Vught, F.A. (2006). Higher education systems dynamics and useful knowledge creation. In: L.E. Weber \& J.J. Duderstadt (eds.). Universities and business: Partnering for the knowledge society. Washington: Brookings Institute Press. 63-76.

Van Vught, F., Van der Wende, M. \& Westerheijden, D. (2002). Globalisation and internationalisation: Policy agendas compared. In: U. Teichler \& J. Enders (eds.). Higher education in a globalising world. Netherlands: Springer. 103-120. https://doi.org/10.1007/978-94-010-0579-1_7

Von Hayek, F.A. (1973). Law, Legislation, and Liberty: A New Statement of the Liberal Principles of Justice and Political Economy (Vol. 1. Rules and Order). London and Henley: Routledge and Kegan Paul.

Wade, R.H. (2004). Is globalization reducing poverty and inequality? World Development, 32(4):567-589. https://doi.org/10.1016/j.worlddev.2003.10.007

Waghid, Y. (2001). Globalization and higher education restructuring in South Africa: Is democracy under threat? Journal of Education Policy, 16(5):455-464. https://doi.org/10.1080/02680930110071048

Wallerstein, I. (1974). The rise and future demise of the world capitalist system: concepts for comparative analysis. Comparative studies in society and history, 16(04):387-415. https://doi.org/10.1017/S001041750 0007520

Woodiwiss, A.J. (2012). Publication subsidies: challenges and dilemmas facing South African researchers. Cardiovascular Journal of Africa, 23(8):421-427.

WSSD (World Summit on Sustainable Development) (2002). Johannesburg declaration on sustainable development. United Nations World Summit on Sustainable Development, New York.

Yang, R. (2003). Globalisation and higher education development: A critical analysis. International Review of Education, 49(3):269-291. https://doi.org/10.1023/A:1025303303245 